\title{
Ecology of Sceloporus gadsdeni (Squamata: Phrynosomatidae) from the central Chihuahuan Desert, Mexico
}

\author{
Héctor Gadsden, ${ }^{1}$ Gamaliel Castañeda, ${ }^{2}$ Rodolfo A. Huitrón-Ramírez, ${ }^{2}$ Sergio A. Zapata- \\ Aguilera, ${ }^{2}$ Sergio Ruíz, ${ }^{1}$ and Geoffrey R. Smith ${ }^{3}$ \\ ${ }^{1}$ Instituto de Ecología, A. C.-Centro Regional del Bajío, Av. Lázaro Cárdenas 253, A. P. 386, C. P. 61600, Pátzcuaro, \\ Michoacán, México. E-mail: hector.gadsden@inecol.mx. \\ ${ }^{2}$ Facultad de Ciencias Biológicas, Universidad Juárez del Estado de Durango, Av. Universidad s/n, Fraccionamiento Filadelfia, \\ Gómez Palacio, 35070, Durango, México. \\ ${ }^{3}$ Department of Biology, Denison University, Granville, Ohio, USA.
}

\begin{abstract}
Ecology of Sceloporus gadsdeni (Squamata: Phrynosomatidae) from the central Chihuahuan Desert, Mexico. Populations of Sceloporus cyanostictus Axtell and Axtell, 1971 from southwestern Coahuila have been described as a new species, Sceloporus gadsdeni Castañeda-Gaytán and Díaz-Cárdenas, 2017. Sceloporus cyanostictus is listed as Endangered by the IUCN Red List due to the decline in its habitat and its limited distribution. The subdivision of $S$. cyanostictus into two species further reduces the range and population size of each taxon, thereby posing a possible threat to the conservation status of each species. We describe here the sexual dimorphism, growth, age, population structure, sex ratio, density, and thermal ecology of S. gadsdeni to supplement the available information for one these two species. Males are larger than females, and when both sexes reach maturity after $1.1 \mathrm{yr}$, they have snout-vent lengths of about $60 \mathrm{~mm}$. Population structures in the spring and summer are similar, and differ from those in the fall. The sex ratio is male-biased and varies seasonally. Population density varies from 29 to 124 individuals/ha. Mean body temperature is $32.1^{\circ} \mathrm{C}$ and mean preferred body temperature is $32.7^{\circ}$ C. Sceloporus gadsdeni is a thermoregulator that has high thermal accuracy $\left(d_{\mathrm{b}}=\right.$ $0.02)$ and optimal thermal efficiency $(E=0.98)$ in an environment with suboptimal thermal quality during September. The data suggest that $S$. gadsdeni is a sexually dimorphic species that has early sexual maturity, relatively slow growth, variable population density, and effective thermoregulation.
\end{abstract}

Keywords: density, growth, population structure, sexual maturity, thermoregulation. 


\begin{abstract}
Resumo
Ecologia de Sceloporus gadsdeni (Squamata: Phrynosomatidae) do Deserto Central de Chihuahua, México. Populações de Sceloporus cyanostictus Axtell e Axtell, 1971 do sudoeste de Coahuila foram descritas como uma nova espécie, Sceloporus gadsdeni Castañeda-Gaytán e DíazCárdenas, 2017. Sceloporus cyanostictus está classificada como Em Perigo na Lista Vermelha da IUCN devido à redução de seu hábitat e distribuição limitada. A subdivisão de $S$. cyanostictus em duas espécies reduz ainda mais a distribuição e o tamanho populacional de cada táxon, impondo assim uma possível ameaça ao status de conservação de cada espécie. Descrevemos aqui o dimorfismo sexual, o crescimento, a idade, a estrutura populacional, a razão sexual, a densidade e a ecologia térmica de $S$. gadsdeni para complementar as informações disponíveis para uma dessas duas espécies. Os machos são maiores que as fêmeas e, quando ambos os sexos atingem a maturidade sexual, após um 1,1 anos, apresentam comprimentos rostro-cloacais de cerca de $60 \mathrm{~mm}$. A estrutura populacional na primavera é similar à do verão, diferindo da do outono. A razão sexual é desviada para os machos e varia sazonalmente. A densidade populacional varia de 29 a 124 indivíduos/ha. A temperatura corporal média é de $32,1^{\circ} \mathrm{C}$ e a temperatura corporal preferida é de $32,7^{\circ} \mathrm{C}$. Sceloporus gadsdeni é um termorregulador de alta acurácia térmica $\left(d_{\mathrm{b}}=0,02\right)$ e eficiência térmica ótima $(E=0,98)$ em um ambiente que apresenta qualidade térmica subótima em setembro. Os dados sugerem que $S$. gadsdeni é uma espécie sexualmente dimórfica que possui maturidade sexual precoce, crescimento relativamente lento, densidade populacional variável e termorregulação eficiente.
\end{abstract}

Palavras-chave: crescimento, densidade, estrutura populacional, maturidade sexual, termorregulação.

\section{Introduction}

Life-history strategies of lizards range from short-lived populations composed of individuals having early sexual maturity, large broods, and high annual reproductive effort to long-lived populations composed of individuals that have delayed sexual maturity, small broods, and low annual reproduction effort. Suites of life history traits, such as clutch size, longevity, age at maturity, and reproductive effort, may or may not be correlated with extinction rates or conservation status of lizard species (Foufopoulos and Ives 1999, Siliceo and Díaz 2010, Tomović et al. 2015, Tingley et al. 2016). Thus, knowledge of the life history of a species is important to generating a coherent conservation plan (e.g., Novaes e Silva et al. 2014), and lack of such information impedes our ability to assess its conservation status (Meiri and Chapple 2016).

Many of the several species of Sceloporus endemic to Mexico are threatened by global warming and habitat loss (Sinervo et al. 2010, Gadsden et al. 2012, Martínez-Méndez et al. 2015). We have extensive knowledge of the ecology and life history of populations of Sceloporus north of the Rio Grande (Tinkle 1967, 1969, Goldberg 1971, Ballinger 1973, 1979, 1980, Tinkle and Hadley 1973, Simon 1975, Ruby 1986, Smith et al. 1994, Smith and Ballinger 1994a, b). However, relatively little is known about the demography and life history of populations from the temperate and desert zones of northern México (Goldberg 1997, Gadsden et al. 2001, Ramírez-Bautista et al. 2002, Gadsden and Estrada-Rodríguez 2007). Our understanding of the potential changes that might occur in these lizard populations must be based on more indepth knowledge of the ecology and natural history of populations of Sceloporus in Mexicoespecially those in the temperate and desert zones of northern Mexico (Goldberg 1997, RamirezBautista et al. 2002, Gadsden and Estrada-Rodríguez 2007, 2008, Gadsden et al. 2008, 2015 a, b). 
Although populations of Sceloporus cyanostictus Axtell and Axtell, 1971 from southwestern Coahuila were described as a new species, Sceloporus gadsdeni Castañeda-Gaytán and DíazCárdenas, 2017 (Díaz-Cárdenas et al. 2017), the population in southeastern Coahuila remains as $S$. cyanostictus. Sceloporus cyanostictus is listed as Endangered in the IUCN Red List given the continuing decline in the extent and quality of its habitat, and its limited distribution $\left(<5000 \mathrm{~km}^{2}\right.$; Vazquez-Díaz et al. 2007), but it is not listed by the Mexican Ministry of the Environment (i.e., NOM-SEMARNAT-059; SEMARNAT 2010). Based on bioclimatic modeling and projections of urban development, Gadsden et al. (2012) predicted a high degree of habitat disturbance and loss for $S$. cyanostictus. (In this study, both southeastern and southwestern populations of Coahuila were included.) In addition, the subdivision of $S$. cyanostictus into two species ( $S$. cyanostictus and $S$. gadsdeni) suggests that the range and population size of each species is even further reduced. Given this recent taxonomic change, it is imperative that the particular threats to each species be assessed by obtaining more data describing their basic biology and ecology as a foundation for planning and implementing specific conservation actions. This is particularly important for $S$. gadsdeni and $S$. cyanostictus because both are confined to "micro islands" of saxicolous habitat surrounded by inhospitable terrain. In addition, these species co-exist with other endemic lizard species. For example, $S$. gadsdeni inhabits a region known as Comarca Lagunera in southwestern Coahuila, a region with eight micro-endemic lizard species that constitute $14 \%$ of the lizard diversity of the Chihuahuan Desert in Mexico (Gadsden et al. 2006, 2012, Barrows et al. 2013). Thus, conservation actions based on information on $S$. gadsdeni likely will benefit the species, as well as other endangered species of the region of Comarca Lagunera. Herein, we describe growth, age, population structure, density, sexual dimorphism, sex ratio, and thermal ecology of a population of S. gadsdeni from the central Chihuahuan Desert in northern Mexico.

\section{Materials and Methods}

\section{Study Area and Field Work}

We conducted field work in Sierra San Lorenzo $\left(25.65^{\circ} \mathrm{N}, 103.17^{\circ} \mathrm{W} ; 1146 \mathrm{~m}\right.$ a.s.l.), $15 \mathrm{~km}$ NE Matamoros, Coahuila, Mexico. The climate of this region is seasonal, with the highest temperature and rainfall occurring in the spring and summer, respectively. Mean annual precipitation is $239 \mathrm{~mm}$ and mean annual temperature is $21^{\circ} \mathrm{C}$ (CONAGUA-SARH 2006). Vegetation is dominated by Yucca filifera Chabaud, Agave lecheguilla Torr., Fouquieria splendens Engelm., Opuntia rufida Engelm., and Opuntia engelmannii Salm-Dyck; and is within the Lechuguilla Scrub (Matorral XerófiloRosetófilo with Agave lecheguilla, see Rzedowski 1978). Throughout the study site, rock faces with crevices are numerous.

Individuals of Sceloporus gadsdeni were collected by noose or hand in three seasonsviz., spring (14-18 April 2009, 17-24 May 2010); summer (21-25 September 2009, 25-29 August 2010); and fall (25-29 November 2009, 01-06 November 2010). Lizards were found on rocks or in rock crevices along a 500-m section of a rocky hill comprising 1.0 ha. On each visit, we attempted to follow the same path. Fieldwork was conducted between 09:00 and 14:00 h every day, a period of time in which similar species are active (Ballinger 1973, Smith and Ballinger 1994b).

Individual lizards were permanently marked by toe-clipping (Ballinger 1973), and temporarily marked with a number written on their back with an ultra-fine-point Sharpie marker with nontoxic ink (Tinkle 1967). Because the lizards shed their skin frequently, identification marks are quickly eliminated, and do not affect their survival. For each capture, we recorded the date; time; body temperature $\left(\mathrm{T}_{\mathrm{b}}\right.$; to nearest $\left.0.1^{\circ} \mathrm{C}\right)$ with a digital thermometer (Fluke ${ }^{\mathrm{TM}}$ model 51II) with a thermocouple inserted into the cloaca immediately upon capture; snout-vent length (SVL) with a plastic ruler (to nearest $\mathrm{mm}$ ); and 
sex. We measured adult head width at the widest point, head length from the anterior edge of the ear to the tip of the snout, and femur length from knee to middle of pelvic region to the nearest $0.01 \mathrm{~mm}$ with calipers. Lizards were released at their exact point of capture.

\section{Sexual Dimorphism and Growth Rates}

Male and female SVLs were compared with an ANOVA. To detect sexual dimorphism in head width, head length, and femur length, we used an analysis of covariance with snout-vent length as the covariate after log- transforming the dependent variables and the covariate because all three variables were significantly influenced by SVL. Unless noted, slopes in the ANCOVAs were homogeneous (as indicated by non-significant sex by SVL interactions in the ANCOVA) and interaction terms were removed from the final model. Means are given $\pm 1 \mathrm{SE}$.

We established four size classes of based on SVL, as follow: Class 1: hatchlings $24-35 \mathrm{~mm}$; Class 2: juveniles 36-47 mm; Class 3: subadults 48-59 mm with 12-mm SVL intervals; and Class 4: adults 60-81 mm (Gadsden and EstradaRodríguez 2008, Gadsden et al. 2008).

The SVLs of marked and recaptured lizards were used to estimate growth curves for both sexes. We used changes in length (dSVL) between captures $(d T)$ to estimate body-growth rates $(G R=d \mathrm{SVL} / d T)$. We only used lizards with recapture intervals between 60 and 460 days in parameter estimation. The growth rate of Sceloporus gadsdeni was evaluated with the von Bertalanffy model (von Bertalanffy 1951, 1957, Fabens 1965). This model estimates growth rate in SVL as a linear function of body length (Gadsden and Castañeda 2013): (1) $G R=a$ $b A S V L$, where $a=$ initial growth rate, $b=$ damping coefficient, and $A S V L=$ average snout vent length (Van Devender 1982). Asymptotic size is predicted by $Z=-a / b$. Equation (1) can be expressed as: (2) $G R=a[1-(\mathrm{SVL} / Z)]$. Knowing the size of neonate lizards $\left(\mathrm{SVL}_{0}\right)$, and using the values of $Z$ and $b$ obtained from $G R=$ $a$ - $b A$ SVL, the growth curve can be obtained using: (3) SVL $=Z\left(1-k e^{-b T}\right)$, where SVL is the size of the lizard after time $T$ (since parturition), $k$ is a constant that can be calculated if $\mathrm{SVL}_{0}$ is known, and $T$ is the number of days of growth (age). $k$ can be estimated as follows: $k=1$ $\mathrm{SVL}_{0} / Z$.

To test the goodness of fit for the growth curves obtained for Sceloporus gadsdeni, we compared the size of lizards of known ages to sizes predicted by the model. The relationship between GR and SVL (separating each sex) was determined by comparing linear regressions between sexes with ANCOVA with SVL as the covariate. For all statistical analysis, only one observation (selected at random) per individual was used. All values are given as means $\pm 1 \mathrm{SE}$.

\section{Population Structure and Dynamics}

The SVL of the lizards at initial capture was used to determine population structure (Griffiths 1999, Ramirez-Bautista et al. 2002) and estimate the sex ratio.

The density of individual adult Sceloporus gadsdeni was estimated using the Schnabel and Schumacher-Eschmeyer extensions of the Peterson method (Krebs 1999); Seber (1982) recommended the Schumacher-Eschmeyer estimator as the most robust for multiple censuses on closed populations. Ballinger (1973) and Ruby (1986) noted that individuals of $S$. jarrovii Cope, 1875 , a species that is ecologically similar to $S$. gadsdeni, were regularly observed in restricted areas with centers of activity situated near specific crevices. We observed similar behavior in S. gadsdeni; therefore, the possibility of migration or immigration of individuals (at least during the short periods of this study) in this population is likely low.

\section{Thermoregulation}

To analyze thermoregulation in Sceloporus gadsdeni, we captured 33 adult lizards (> 60.0 $\mathrm{mm}$ SVL, 18 females and 15 males) at a 
considerable distance from the marked population in September 2009 (Gadsden et al. 2015b). Immediately after capture, we recorded the date, time, $\mathrm{T}_{b}$, air temperature $\left(\mathrm{T}_{a}\right.$; thermometer $1 \mathrm{~cm}$ above substrate where individual was first observed), and substrate temperature $(\mathrm{T}$; thermometer touching substrate where individual was first observed) with a digital thermometer (Fluke ${ }^{\mathrm{TM}}$ model 51-II). To evaluate thermoregulatory efficiency ( $E$; Hertz et al. 1993), we used $T_{b}$ of this sample taken in the wild, preferred temperature of these individuals measured on a thermal gradient $\left(20-50^{\circ} \mathrm{C}\right)$ in the laboratory (Gadsden et al. 2015b). Operative temperature $\left(\mathrm{T}_{\mathrm{e}}\right)$ was recorded using six datalogger sensors connected to previously fieldcalibrated PVC models similar in size and shape to $S$. gadsdeni $(63 \times 15 \mathrm{~mm}$, corresponding to the mean SVL of adult lizards). The models were sealed at each end and painted the same color as S. gadsdeni; they were connected to dataloggers (HOBO ${ }^{\circledR}$ Pro v2) painted with $33 \%$ reflective gray spray paint (Rustoleum ${ }^{\mathrm{TM}}$ gray primer) to approximate the reflectivity of phrynosomatids (Adolph 1990). The models were then placed in three rocky microsites occupied by the lizards ( 2 in sunny sites, 2 in shade, and 2 in sun/shade mosaic) (Sinervo et al. 2011). We recorded temperatures every $30 \mathrm{~min}$ from 10:00-19:00 $\mathrm{h}$ for 3 days to estimate the distribution of $\mathrm{T}_{\mathrm{e}}$ throughout the potential daily activity period (Pianka and Parker 1975, Dzialowski 2005). Calibration of lizard and PVC model (every $3 \mathrm{~min}$ for $3 \mathrm{~h}$ ) in both sunny and shaded microhabitats (Lara-Reséndiz et al. 2014), gave a highly significant linear relationship between field $\mathrm{T}_{\mathrm{b}}$ and $\mathrm{T}_{\mathrm{e}}(N=54, \mathrm{r}=0.93, p$ $\left.<0.001 ; \mathrm{T}_{\mathrm{b}}=1.16 \mathrm{~T}_{\mathrm{e}}-5.34\right)$. Thus, we assumed the lizard models accurately measured the available $\mathrm{T}_{\mathrm{e}}$ for $S$. gadsdeni in this study, especially during the hours of activity $\left(\mathrm{T}_{\mathrm{b}}>24^{\circ} \mathrm{C}\right)$.

Indices of thermoregulatory accuracy $\left(d_{\mathrm{b}}\right)$ and habitat thermal quality $\left(d_{\mathrm{e}}\right)$ were calculated from these data (Lara-Reséndiz et al. 2015). High values of $d_{\mathrm{b}}$ indicate low thermoregulatory precision, whereas values of $d_{b}$ equal to or near 0 indicate high thermoregulatory precision. High values of $d_{\mathrm{e}}$ indicate low habitat thermal quality from the organism's perspective, whereas values equal to or near 0 indicate thermally ideal environments. We calculated thermoregulatory efficiency $(E)$ using the equation $\left(E=1-d_{\mathrm{b} \text { mean }}\right.$ ' $\left.d_{\text {e mean }}\right)$. If $E$ is near 0 , lizards do not thermoregulate efficiently (i.e., they are thermoconformers). If $E$ is near 1, lizards are efficient thermoregulators. After completion of the laboratory experiments, we released all lizards at their capture sites.

\section{Results}

\section{Sexual Dimorphism and Growth Rates}

Adult males are significantly larger than adult females (Table 1; $F_{1,22}=8.6, p<0.01$ ) and have wider, longer heads than do females (Table $\left.1 ; F_{1,22}=12.2, p<0.01 ; F_{1,22}=13.7, p<0.01\right)$. Both head width and length are significantly related to SVL (Table 1; $F_{1,22}=49.5, p<0.01$; $\left.F_{1,22}=39.6, p<0.01\right)$. Likewise, the femurs of males are longer than those of females (Table 1; $F_{1,22}=7.3, p<0.02$ ), and femur length is significantly related to $\operatorname{SVL}\left(F_{1,22}=29.4, p<0.01\right)$.

Growth is significantly higher in hatchlings and juveniles than in subadults and adults (Figure 1; ANOVA, $F_{3,23}=90.17, p<0.0001$ ). Males and females do not differ in growth rates (Figure 2 ; ANCOVA $F_{1,33}=2.74, p=0.10$ ). Growth rate decreases significantly with respect to SVL (Figure 2; $F_{1,33}=24.3, p<0.0001$ ).

To estimate the growth curve constants, we used the same $\mathrm{SVL}_{0}(27.4 \mathrm{~mm}$; age of $\sim 30.0$ days) for both sexes. Based on the estimated growth curves, males and females reach an adult SVL of $60 \mathrm{~mm} \mathrm{SVL}$ at an average age of $1.1 \mathrm{yr}$. Males reach an asymptote of $\sim 77 \mathrm{~mm}$ SVL and females of $\sim 80$ SVL at an approximate ages of 3.3 and $2.7 \mathrm{yr}$, respectively (Figure 3).

\section{Population Structure and Dynamics}

The spring and summer population structures of Sceloporus gadsdeni are similar and differ 
Table 1. Morphological measurements of adult male and female Sceloporus gadsdeni from Sierra San Lorenzo, Coahuila, Mexico. Means are given $\pm 1 \mathrm{SE}$.

\begin{tabular}{lcc}
\hline & Males $(\boldsymbol{N}=\mathbf{1 4})$ & Females $(\mathbf{N}=\mathbf{1 0})$ \\
\hline SVL $(\mathrm{mm})$ & $68.8 \pm 1.3$ & $63.5 \pm 1.0$ \\
Head width $(\mathrm{mm})$ & $15.6 \pm 0.4$ & $13.6 \pm 0.4$ \\
Head length $(\mathrm{mm})$ & $18.2 \pm 0.3$ & $16.4 \pm 0.2$ \\
Femur length $(\mathrm{mm})$ & $15.1 \pm 0.2$ & $13.8 \pm 0.4$ \\
\hline
\end{tabular}

from that of the fall (Figure 4; $\chi^{2}=21.3, d f=8$, $p<0.01)$. Notably, in the spring and summer, hatchlings and juveniles are present. The relative number of adult females and males (SVL $\geq 60$ $\mathrm{mm})$ differed significantly in 2009 and 2010 $\left(\chi^{2}=14.1, d f=2, p<0.005\right)$. Adult males were most numerous in summer and fall 2010 and adult females were the most numerous in springs of 2009 and 2010.

The seasonal sex ratio in 2009 was heavily biased toward males in summer and fall (3.0 and 3.0, respectively), but biased toward females $(0.4)$ in the spring. The same pattern was observed in 2010 when in summer and fall the values for males were 1.6 and 11.0, respectively, and in the spring the value for females was (0.75). The overall sex ratio (3 seasons pooled 2009 and 2010) is 1.8 (38 males:21 females), which differs significantly from $1: 1\left(\chi^{2}=4.90\right.$, $d f=2, p=0.027)$.

The densities (Schnabel) of adult Sceloporus gadsdeni in April, September, and November (2009) are 65.02, 95.65, and 28.9 animals/ha, respectively. The densities in May, August, and November (2010) are 161.12, 184.24, and 80.92 animals/ha, respectively. Schumacher-Eschmeyer estimates of $S$. gadsdeni are similar to those obtained by the Schnabel method.

\section{Thermoregulation}

Mean $\mathrm{T}_{\mathrm{b}}$ (females and males pooled) is 32.1 $\pm 0.4^{\circ} \mathrm{C}$ (range $22.0-38 \cdot 1^{\circ} \mathrm{C} ; N=33$ ). Mean $\mathrm{T}_{\mathrm{b}}$ for males was $32.5 \pm 0.6^{\circ} \mathrm{C}$ (range $29.0-38.1^{\circ} \mathrm{C}$;

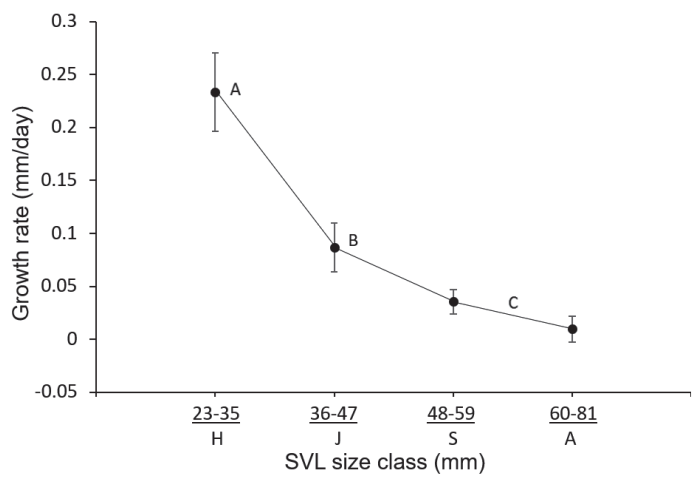

Figure 1. Mean $( \pm 1 \mathrm{SD})$ growth rates of SVL size classes of the lizard Sceloporus gadsdeni. Values having different capital letters are significantly different (Tukey's test: $p<0.05$ per comparison). $\mathrm{H}=$ hatchlings $(\mathrm{N}=3), \mathrm{J}=$ juveniles $(N=4), S=$ subadults $(N=9)$, and $A=$ adults $(N=8)$.

$N=15$ ), and for females is $31.5 \pm 0.6^{\circ} \mathrm{C}$ (range $22.0-35.2^{\circ} \mathrm{C} ; N=18$ ). There are no significant differences in mean $\mathrm{T}_{\mathrm{b}}$ between males and females $(\mathrm{H}=0.52, d f=1, p>0.05)$.

Body temperature is positively related to $\mathrm{T}_{\mathrm{s}}$ $\left(N=33, \mathrm{r}^{2}=0.36, p<0.001, \mathrm{~T}_{\mathrm{b}}=0.40 \mathrm{~T}_{\mathrm{s}}+\right.$ $19.8)$. Body temperature is positively related to $\mathrm{T}_{\mathrm{a}}\left(N=33, \mathrm{r}^{2}=0.45, p<0.001, \mathrm{~T}_{\mathrm{b}}=0.47 \mathrm{~T}_{\mathrm{a}}+\right.$ 18.0).

Preferred body temperature and mean operative temperature are $32.7 \pm 0.2^{\circ} \mathrm{C}$ (range $24.4-38.4^{\circ} \mathrm{C}, N=33$ ) and $36.4 \pm 0.3^{\circ} \mathrm{C}$ (range 28.2-53.6, $N=186)$, respectively. The 


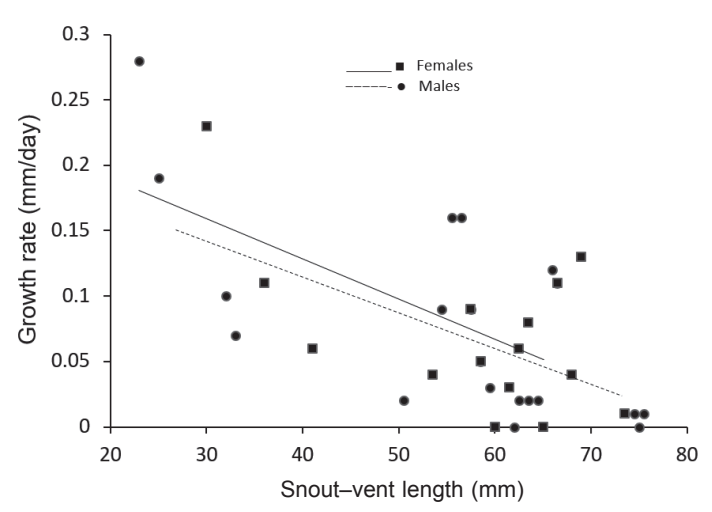

Figure 2. Growth rate of male and female Sceloporus gadsdeni as a function of body size (SVL). Each point represents growth rate $(G R)$ and average snout-vent length obtained for lizards with recapture intervals of 60-360 days. Regression equations-Females: $y=-0.0030$ $x+0.250, R=0.58$; Males: $y=-0.0028 x+$ $0.229, R=0.58$.

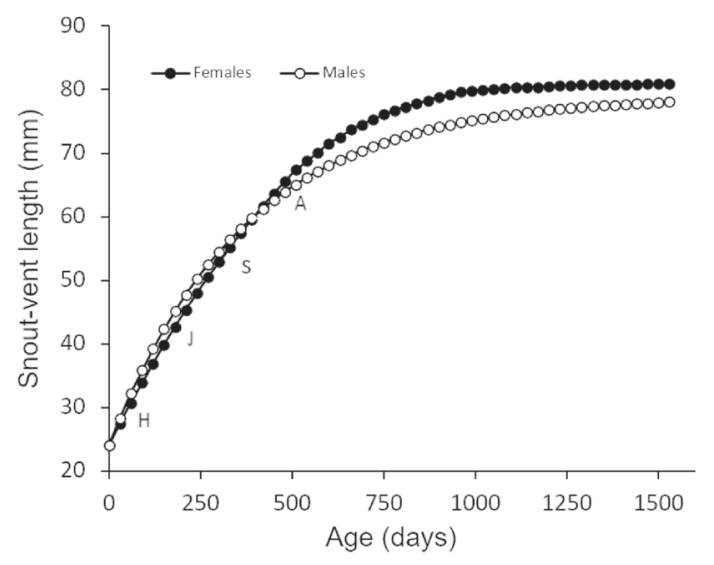

Figure 3. Growth curves of von Bertalanffy model for females and males of the lizard Sceloporus gadsdeni. Abscissa shows age (days); ordinate shows SVL $(\mathrm{mm})$. Estimated from the equation of Fabens (1965), with an initial SVL $=28.27$ $\mathrm{mm}$ vs. 30 days old. The values used were $a=$ 0.3690 and $b=0.0089$ for males, and $a=$ 0.3444 and $b=0.0080$ for females. Circles represent means.

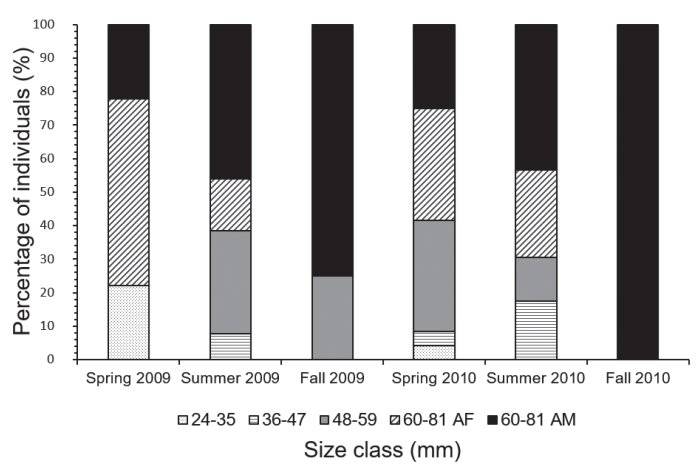

Figure 4. Percentage of individual Sceloporus gadsdeni in different size classes in spring, summer, and fall. Size classes: $24-35 \mathrm{~mm}=$ hatchlings, 36-47 $\mathrm{mm}=$ juveniles, $48-59 \mathrm{~mm}=$ subadults, $60-81 \mathrm{~mm}=$ adult females (AF), and $60-81 \mathrm{~mm}=$ adult males (AM).

thermoregulation accuracy index $\left(d_{\mathrm{b}}\right)$ is $0.02 \pm$ $0.008(N=33)$. The thermal quality index $\left(d_{\mathrm{e}}\right)$ is $1.66 \pm 0.24(N=186)$ and the thermal efficiency $(E)$ of this population is 0.98 .

\section{Discussion}

\section{Sexual Dimorphism and Growth Rates}

Male Sceloporus gadsdeni have larger snoutvent lengths, head widths, head lengths, and femur lengths than females. The species resembles many other Sceloporus in being sexually dimorphic in size (Fitch 1978, JiménezArcos et al. 2017); this includes the closely related S. cyanostictus (Axtell and Axtell 1971), S. minor Cope, 1885 (Ramírez-Bautista et al. 2008, 2014, García-Rosales et al. 2017), and $S$. poinsettii Baird and Girard, 1852 (Gadsden et al. 2005). Sceloporus gadsdeni seems to fall in the S. poinsettii species group (Wiens et al. 2010). Fitch (1978) argued that species in the $S$. poinsettii Group tend to lack significant sexual size dimorphism. However, Jiménez-Arcos et al. (2017) reported that there is marginal, malebiased sexual size dimorphism in the group, and 
our results support this finding. Sexual dimorphism might result from sexual selection, either through female choice of large-headed males or through male-male aggression resulting in the winner, usually the one having a larger head, obtaining greater access to females (Shine 1989). Sexual dimorphism also might result from intraspecific niche divergence, in which males and females eat different prey, because differences in head size can lead to use of different-sized prey items (Shine 1989). In $S$. jarrovii and S. virgatus Smith, 1938, sexual size dimorphism results from differential growth rates (Cox and John-Alder 2007), which likely underlies most sexual size dimorphism in Sceloporus and other lizards. The disparate growth rates may reflect differential allocations of energy by males versus females to meet the competing demands of reproduction, growth, and behavior (Cox et al. 2007). Male and female S. gadsdeni do not statistically differ in growth rate, but females seem to have a slightly grreater asymptotic SVL than do males (Figure 3). Our results suggest that rather than differential growth, differential survivorship of adult males and females explains sexual size dimorphism. However, more research is needed to identify the proximate mechanism responsible for the observed sexual dimorphism in size in $S$. gadsdeni.

In Sierra San Lorenzo (1146 m a.s.l.) the mean growth rate for Sceloporus gadsdeni is $0.08 \mathrm{~mm} \mathrm{~d}^{-1}$. This growth rate is lower than those of $S$. jarrovii (high elevation: $0.16 \mathrm{~mm} \mathrm{~d}^{-1}$, low elevation: $0.12 \mathrm{~mm} \mathrm{~d}^{-1}$; Smith and Ballinger 1994a). The explanation for lower growth rates in $S$. gadsdeni is unknown, but they may reflect differences in elevation (lower in S. gadsdeni), prey abundance (e.g., Smith and Ballinger 1994a, Smith 1998), thermal constraints (e.g., Grant and Dunham 1990, Sinervo and Adolph 1994, Niewiarowski 2001), or genetic or evolutionary causes (e.g., Niewiarowski and Roosenburg 1993, Smith et al. 1994, Sears and Angilletta Jr. 2003).

\section{Population Structure and Dynamics}

The density of adult Sceloporus gadsdeni in San Lorenzo fluctuated between 29 and 184 lizards $\mathrm{ha}^{-1}$. Of the many factors that can influence the density of lizards, two are the availability of food and the thermal environment of their habitat (Rose 1982, Christian and Tracy 1985, Sinervo 1990). The density of adult $S$. gadsdeni was higher in summer 2010 than in the previous seasons and subsequent fall. Whitford and Creusere (1977) suggested that the density of most lizard species varies directly with changes in productivity and relative abundance of arthropods. Likewise, availability of insect prey changes according to distribution and amount of rain throughout year (Maury 1995, Siliceo-Cantero and García 2014). Indeed, positive correlations between precipitation and density or abundance seem to be relatively common in lizards (Castaneda-Gaytan et al. 2003, Barrows and Allen 2010, Robinson and Barrows 2013, Dibner et al. 2017); there also is evidence that precipitation affects the recruitment of individuals into the population (e.g., Read et al. 2012). Thus, the large increase we observed may reflect higher recruitment of adults in early summer 2010 as a result of higher than normal precipitation earlier in the year.

For all viviparous species of Sceloporus (except S. bicanthalis Smith, 1937), vitellogenesis is initiated in late summer or autumn; gestation continues throughout the winter, and parturition occurs in spring (Méndez-de la Cruz et al. 1998). The reproductive cycle of $S$. gadsdeni (or $S$. cyanostictus) has not been studied; however, we found a female $S$. gadsdeni with seven embryos in an advanced stage of development in April 2009 (H. Gadsden, pers. observ.). This suggests that gestation in this species probably probably occurs during the winter as it does in many viviparous Sceloporus. Hatchlings of S. gadsdeni were encountered in the spring 2009 and 2010; this also supports fall mating, winter gestation, and spring parturition as is common in viviparous Sceloporus (Méndez-de la Cruz et al. 1998, 
Gadsden et al. 2008, Villagran-Santa Cruz et al. 2009).

\section{Thermoregulation}

Mean $\mathrm{T}_{b}$ of Sceloporus gadsdeni in San Lorenzo is $32^{\circ} \mathrm{C}$. This value is within the range observed in the $S$. poinsettii $\left(29.4-34.2^{\circ} \mathrm{C}\right)$ and S. torquatus species groups $\left(31.0-34.5^{\circ} \mathrm{C}\right)$ (reviewed in Lara-Reséndiz et al. 2014). Furthemore, these means fall within the range usually observed in Sceloporus $\left(28.6-36.9^{\circ} \mathrm{C}\right.$; Andrews 1998). Our results support the contention that, as a genus, Sceloporus is thermally conservative (Andrews 1998, Grigg and Buckley 2013).

We found that Sceloporus gadsdeni thermoregulate, displaying high thermal accuracy $\left(d_{\mathrm{b}}=0.02\right)$ and optimal thermal efficiency $(E=$ 0.98 ) in an environment that has a suboptimal thermal quality $\left(d_{\mathrm{e}}=1.6\right)$. Likewise, body temperature $\left(\mathrm{T}_{\mathrm{b}}\right)$ is positively related both to substrate temperature $\left(\mathrm{T}_{\mathrm{s}}\right)$ and air temperature $\left(T_{a}\right)$. However, $T_{b}$ is more related to $T_{a}$. Therefore, according to Huey and Slatkin (1976), we assume that $S$. gadsdeni tends to be heliothermic. However, this species also conducts heat to its body through contact with rocks in its environment.

This study was limited to the month of September. In other phrynosomatids (e.g., Uta stansburiana Baird and Girard, 1852 and Sceloporus undulatus Bosc and Daudin, 1801), thermoregulatory behavior can vary seasonlly and change thermoregulatory efficiency $(E)$ (e.g., Waldschmidt 1980). Therefore, we only can say that during late summer, S. gadsdeni is an effective thermoregulator. For example, daily activity patterns and preferred body temperature $\left(\mathrm{T}_{\mathrm{p}}\right)$ of heliotermic lizards (e.g., S. undulatus) can vary significantly among seasons and their thermoregulatory efficiency can vary throughout the year (Angilletta 2001). In addition, daily activity patterns in many desert phrynosomatids (e.g., Uma exsul Schmidt and Bogert, 1947 and Uta stansburiana Baird and Girard, 1852) are bimodal during spring and summer, but unimodal in autumn (García-de la Peña et al. 2007), suggesting that behavioral shifts in thermoregulatory activity are likely. Therefore, additional study is needed to determine whether thermoregulation in $S$. gadsdeni changes seasonally, or whether they are effective thermoregulators (as in September) throughout the year.

Changes in a lizard's thermal environment can limit foraging and constrain growth and reproduction, affecting population growth and increasing extinction risk (Sinervo et al. 2010), even in thermoregulators (Buckley et al. 2015). Thus, any change in the lower $\left(\mathrm{T}_{\min }\right)$ or upper $\left(\mathrm{T}_{\max }\right)$ temperatures experienced by lizards may affect their ability to remain in the environment. The rate of change in $\mathrm{T}_{\max }$ (maximum air temperature) seems to be greatest in the winterspring (January-May) and increases more rapidly in northern and central Mexico (Sinervo et al. 2010). The rate of change in $\mathrm{T}_{\max }$ during the winter-spring breeding periods and local extinctions of Sceloporus populations are correlated (Sinervo et al. 2010). Gadsden et al. (2012) used ecological niche modeling (MaxEnt) to estimate the future geographic distribution of S. cyanostictus (sensu lato). Strong climatic changes are projected to occur in the central Chihuahuan Desert in the coming decades, particularly in the period 2020-2050. Effects of these climatic changes are expected to affect the geographic distribution of $S$. cyanostictus. Under the A2 scenario (liberal model), a $61 \%$ reduction of the modeled range of $S$. cyanostictus is expected by 2020. In 2050, the picture looks even worse because the distribution of $S$. cyanostictus is predicted to be decreased by $84 \%$ (Gadsden et al. 2012). This suggests that $S$. gadsdeni could be threatened by global warming.

Additional studies on other members of the $S$. torquatus and $S$. poinsettii groups in Mexico are needed to explain any variation or similarities in the ecologies of the many endemic species of each of these diverse groups of lizards. Likewise, intraspecific and interspecific comparisons of 
members of these two groups from dissimilar geographic and climatic locations would inform the way in which different environmental conditions influence the population structure and dynamics of these lizards. The research must obtain data on growth, survivorship, density, temperature, moisture, predator pressure, and food availability to gain a better understanding of adaptation and the ecological relationships of genus Sceloporus. Such studies are critical given the substantial reductions of viable habitats projected for species in these groups owing to climate change and other human activities (e.g., Sinervo et al. 2010, Gadsden et al. 2012, Martínez-Méndez et al. 2015).

\section{Acknowledgments}

Permit granted by Secretaría de Medio Ambiente y Recursos Naturales (SEMARNATSGPA/DGVS/07946/08) to Hector Gadsden. We thank two anonymous reviewers for comments that improved the manuscript.

\section{References}

Adolph, S. C.1990. Influence of behavioral thermoregulation on microhabitat use by two Sceloporus lizards. Ecology 71: 315-327.

Andrews, R. M. 1998. Geographic variation in field body temperature of Sceloporus lizards. Journal of Thermal Biology 23: 329-334.

Angilletta, M. J. Jr. 2001. Thermal and physiological constraints on energy assimilation in a widespread lizard (Sceloporus undulatus). Ecology 82: 3044-3056.

Axtell, R. W. and C. A. Axtell. 1971. A new lizard (Sceloporus jarrovii cyanostictus) from the Sierra Madre of Coahuila, Mexico. Copeia 1971: 89-98.

Ballinger, R. E. 1973. Comparative demography of two viviparous iguanids lizards (Sceloporus jarrovi and Sceloporus poinsetti). Ecology 63: 679-687.

Ballinger, R. E. 1979. Intraspecific variation in demography and life history of the lizard, Sceloporus jarrovi, along an altitudinal gradient in southeastern Arizona. Ecology 60: 901-909.
Ballinger, R. E. 1980. Food limiting effects in populations of Sceloporus jarrovi (Iguanidae). Southwestern Naturalist 25: $554-557$.

Barrows, C. W. and M.F. Allen. 2010. Patterns of occurrence of reptiles across a sand dune landscape. Journal of Arid Environments 74: 186-192.

Barrows, C. W., H. Gadsden, M. Fisher, C. García-De la Peña, G. Castañeda, and H. López- Corrujedo. 2013. Patterns of lizard species richness within National Parks and Biosphere Reserves across North America's deserts. Journal of Arid Environments 95: 41-48.

Buckley, L. B., J. C. Ehrenberger, and M. J. Angilletta Jr. 2015. Thermoregulatory behaviour limits local adaptation of thermal niches and confers sensitivity to climate change. Functional Ecology 29: 1038-1047.

Castañeda-Gaytán, G., H. Gadsden, H. Lopéz-Corrujedo, and J. L. Estrada-Rodríguez. 2003. Historía de vida de Uma paraphygas (Sauria: Phrynosomatidae) en la reserve de la Biosfera de Mapimí, Durango. Acta Zoologica Mexicana 89: 169-184.

Christian, K. A. and C. R. Tracy. 1985. Physical and biotic determinants of space utilization by the Galapagos land iguana (Conolophus pallidus). Oecologia 66: 132-140.

CONAGUA-SARH. 2006. Dirección de Hidrología, Departamento de Cálculo Hidrometrico y Climatológico. Durango. Estación Lerdo.

Cox, R. M. and H. B. John-Alder. 2007. Growing apart together: the development of contrasting sexual size dimorphism in sympatric Sceloporus lizards. Herpetologica 63: 245-257.

Cox, R. M., M. A. Butler, and H. B. John-Alder. 2007. The evolution of sexual size dimorphism in reptiles. Pp. 38 49, in D. J. Fairbairn, W. U. Blanckenhorn, and T. Székely (eds.), Sex, Size and Gender Roles: Evolutionary Studies of Sexual Size Dimorphism. Oxford. Oxford University Press.

Díaz-Cárdenas, B., E. Ruiz-Sánchez, P. Castro-Félix, G. Castañeda-Gaytán, S. Ruiz-Santana, and H. Gadsden. 2017. Species delimitation of the blue-spotted spiny lizard within a multilocus, multispecies coalescent framework, results in the recognition of a new Sceloporus species. Molecular Phylogenetics and Evolution 111: 185-195.

Dibner, R. R., D. F. Doak, and M. Murphy. 2017. Discrepancies in occupancy and abundance approaches to identifying and protecting habitat for an at-risk species. Ecology and Evolution 7: 5692-5702.

Dzialowski, E. M. 2005. Use of operative temperature and standard operative temperature models in thermal biology. Journal of Thermal Biology 30: 317-334. 
Fabens, A. J. 1965. Properties and fittings of the von Bertalanffy growth curve. Growth 29: 265-289.

Fitch, H. S. 1978. Sexual size differences in the genus Sceloporus. University of Kansas Science Bulletin 51: 441-461.

Foufopoulos, J., and A. R. Ives. 1999. Reptile extinctions on land-bridge islands: life-history attributes and vulnerability to extinction. American Naturalist 153: $1-25$.

Gadsden, H. and J. L. Estrada-Rodríguez. 2007. Ecology of the spiny lizard Sceloporus jarrovii in the central Chihuahuan Desert. Southwestern Naturalist 52: 600608.

Gadsden, H. and J. L. Estrada-Rodríguez. 2008. Demography of the Yarrow's spiny lizard, Sceloporus jarrovii from central Chihuahuan Desert. Western North American Naturalist 68: 46-57.

Gadsden, H. and G. Castañeda. 2013. Life history of the Marbled Whiptail Lizard Aspidoscelis marmorata from the central Chihuahuan Desert of Mexico. Acta Herpetologica 8: 81-91.

Gadsden, H., L. E. Palacios-Orona, and G. Cruz-Soto. 2001. Diet of the Mexican fringe-toed lizard (Uma exsul). Journal of Herpetology 35: 493-496.

Gadsden, H., J. L. Estrada-Rodríguez, and S. V. LeyvaPacheco. 2006. Checklist of amphibians and reptiles of the "Comarca Lagunera" in Durango-Coahuila, Mexico. Bulletin of the Chicago Herpetological Society 41: 2-9.

Gadsden, H., S. Ruíz, and G. Castañeda. 2015a. Sceloporus jarrovii and Sceloporus poinsettii. Preferred body temperature. Herpetological Review 46: 261-262.

Gadsden, H., G. Castañeda, and R. A. Huitrón-Ramírez. 2015b. Sceloporus cyanostictus. Field and preferred body temperature. Herpetological Review 46: 436-437.

Gadsden, H., F. de J. Rodríguez-Romero, F. R. Méndez-de la Cruz, and R. Gil-Martínez. 2005. Ciclo reproductor de Sceloporus poinsettii Baird y Girard, 1852 (Squamata: Phrynosomatidae) en el centro del Desierto Chihuahuense, México. Acta Zoologica Mexicana 21: $93-107$.

Gadsden, H., C. Ortiz-Lomas, R. Gil-Martínez, S. V. LeyvaPacheco, J. L. Estrada-Rodríguez, and G. R. Smith. 2008. Reproductive cycle of the spiny lizard Sceloporus jarrovii from the central Chihuahuan Desert, Mexico. Herpetological Journal 18: 205-211.

Gadsden, H., C. Ballesteros-Barrera, O. Hinojosa de la Garza, G. Castañeda, C. García-De la Peña, and J. A. Lemos-Espinal. 2012. Effects of land-cover transformation and climate change on the distribution of two endemic lizards, Crotaphytus antiquus and Sceloporus cyanostictus, of northern Mexico. Journal of Arid Environments 83: 1-9.

García-de la Peña, C., H. Gadsden, A. Contreras-Balderas, and G. Castañeda. 2007. Ciclos de actividad diaria y estacional de un gremio de saurios en las dunas de arena de Viesca, Coahuila, México. Revista Mexicana de Biodiversidad, Instituto de Biología, Universidad Nacional Autónoma de México 78: 141-147.

García-Rosales, A., A. Ramírez-Bautista, B. P. Stephenson, R. N. Meza-Lázaro, and A. Nieto-Montes de Oca. 2017. Comparative morphology and genetics of two populations of spiny lizards (genus Sceloporus) from central Mexico. Zoologisches Anzeiger 267: 21-30.

Goldberg, S. R. 1971. Reproductive cycle of the ovoviviparous iguanid lizard Sceloporus jarrovi Cope. Herpetologica 27: 123-131.

Goldberg, S. R. 1997. Sceloporus jarrovii (Yarrow's spiny lizard). Reproduction in México. Herpetological Review 28: 204 .

Grant, B. W. and A. E. Dunham. 1990. Elevational covariation in environmental constrains in life histories of the desert lizard Sceloporus merriami. Ecology 71: $1765-1776$.

Griffiths, A. D. 1999. Demography and home range of the frillneck lizard, Chlamydosaurus kingii (Agamidae), in Northern Australia. Copeia 1999: 1089-1096.

Grigg, J. W. and L. B. Buckley. 2013. Conservatism of lizard termal tolerances and body temperatures across evolutionary history and geography. Biology Letters 9: 20121056.

Hertz P. E., R. B. Huey, and R. D. Stevenson. 1993. Evaluating temperature regulation by field-active ectotherms - the fallacy of the inappropriate question. American Naturalist 42: 796-818.

Huey, R. B. and M. Slatkin. 1976. Cost and benefits of lizard thermoregulation. Quarterly Review of Biology 51: 363 384.

Jiménez-Arcos, V. H., S. Sanabria-Urbán, and R. Cueva del Castilla. 2017. The interplay between natural and sexual selection in the evolution of sexual size dimorphism in Sceloporus lizards (Squamata: Phrynosomatidae). Ecology and Evolution 7: 905-917.

Krebs, C. J. 1999. Ecological Methodology. Menlo Park. Benjamin/Cummings. 620 pp.

Lara-Reséndiz, R. A., A. H. Díaz de la Vega-Pérez, V. H. Jiménez-Arcos, H. Gadsden, and F. R. Méndez-de la 
Cruz. 2014. Termorregulación de dos poblaciones de lagartijas simpátridas: Sceloporus poinsettii y Sceloporus lineolateralis (Squamata: Phrynosomatidae) en Durango, México. Revista Mexicana de Biodiversidad 85: $875-884$

Lara-Reséndiz, R. A., H. Gadsden, P. C. Rosen, B. Sinervo, and F. R. Méndez-de la Cruz. 2015. Thermoregulation of two sympatric species of horned lizard in the Chihuahuan Desert and their local extinction risk. Journal of Thermal Biology 48: 1-10.

Martínez-Méndez, N., O. Mejía, and F. R. Méndez de la Cruz. 2015. The past, present and future of a lizard: the phylogeography and extinction risk of Sceloporus serrifer (Squamata: Phrynosomatidae) under a global warming scenario. Zoologisches Anzeiger 254: 86-98.

Maury, M. E. 1995. Diet composition of the greater earless lizard (Cophosaurus texanus) in central Chihuahuan Desert. Journal of Herpetology 29: 266-272.

Meiri, S., and D.G. Chapple. 2016. Biases in the current knowledge of threat status in lizards, and bridging the 'assessment gap'. Biological Conservation 204: 6-15.

Méndez-de la Cruz, F. R., M. Villagrán-Santa Cruz, and R. M. Andrews. 1998. Evolution of viviparity in the lizard Genus Sceloporus. Herpetologica 54: 521-532.

Novaes e Silva, V., R. L. Pressey, R. B. Machado, J. Van Der Wal, H. C. Wiederhecker, F. P. Werneck, and G. R. Colli. 2014. Formulating conservation targets for a gap analysis of endemic lizards in a biodiversity hotspot. Biological Conservation 180: 1-10.

Niewiarowski, P. H. 2001. Energy budgets, growth rates, and thermal constraints: toward an integrative approach to the study of life-history variation. American Naturalist 157: 421-433.

Niewiarowski, P. H. and W. Roosenburg. 1993. Reciprocal transplant reveals sources of variation in growth rates of the lizard Sceloporus undulatus. Ecology 74: 1992 2002.

Pianka, E. R. and W. S. Parker. 1975. Ecology of horned lizards: review with special reference to Phrynosoma platyrhinos. Copeia 1975: 141-162.

Ramírez-Bautista, A., O. Ramos-Flores, and J. W. Sites Jr. 2002. Reproductive cycle of the spiny lizard Sceloporus jarrovii (Sauria: Phrynosomatidae) from north-central Mexico. Journal of Herpetology 36: 225-233.

Ramírez-Bautista, A., O. Ramos-Flores, B. P. Stephenson, and G. R. Smith. 2008. Reproduction and sexual dimorphism in two populations of Sceloporus minor of the Guadalcázar Region, San Luis Potosí, Mexico. Herpetological Journal 18: 121-127.
Ramírez-Bautista, A., B. P. Stephenson, C. Serrano Muñoz, R. Cruz-Elizalde, and U. Hernández-Salinas. 2014. Reproduction and sexual dimorphism in two populations of the polymorphic spiny lizard Sceloporus minor from Hidalgo, México. Acta Zoologica 95: 397-408.

Read, J. L., K.-J. Kovac, B. W. Brook, and D. A. Fordham. 2012. Booming during a bust: asynchronous population responses of arid zone lizards to climatic variables. Acta Oecologica 40: 51-61.

Robinson, M. D., and C. W. Barrows. 2013. Namibia and North American sand-diving lizards. Journal of Arid Environments 93: 116-125.

Rose, B. 1982. Lizard home range: methodology and functions. Journal of Herpetology 16: 253-269.

Ruby, D. E. 1986. Selection of home range site by females of the lizard, Sceloporus jarrovi. Journal of Herpetology 20: $466-469$.

Rzedowski, J. 1978. Vegetación de México. México. Limusa. $504 \mathrm{pp}$.

Sears, M. W. and M. J. Angilletta Jr. 2003. Life-history variation in the sagebrush lizard: Phenotypic plasticity or local adaptation? Ecology 84: 1624-1634.

Seber, G. A. F. 1982. The Estimation of Animal Abundance and Related Parameters. $2^{\text {nd }}$ Edition. London. Charles Griffin. 672 pp.

SEMARNAT (Secretaría de Medio Ambiente y Recursos Naturales). 2010. Norma Oficial Mexicana NOM-059ECOL-2010, Protección ambiental. Especies nativas de México de flora y fauna silvestres. Categorías de riesgo y especificaciones para su inclusión, exclusión o cambio. Lista de especies en riesgo. Diario Oficial de la Federación, segunda sección, jueves 30 de diciembre de 2010.

Shine, R. 1989. Ecological causes for the evolution of sexual dimorphism: a review of the evidence. Quarterly Review of Biology 64: 419-464.

Siliceo, I. and J.A. Díaz. 2010. A comparative study of clutch size, range size, and the conservation status of island vs. mainland lacertid lizards. Biological Conservation 143: 2601-2608.

Siliceo-Cantero, H., and A. García. 2014. Differences in growth rate, body condition, habitat use and food availability between island and mainland lizard populations of Anolis nebulosus in Jalisco, Mexico. Journal of Tropical Ecology 30: 493-501.

Simon, C. A. 1975. The influence of food abundance on territory size in the iguanid lizard Sceloporus jarrovi. Ecology 56: 993-998. 
Sinervo, B. 1990. Evolution of thermal physiology and growth rate between populations of the western fence lizard (Sceloporus occidentalis). Oecologia 83: 228 237.

Sinervo, B. and S. C. Adolph. 1994. Growth plasticity and thermal opportunity in Sceloporus lizards. Ecology 75: 776-790.

Sinervo, B. R., F. Méndez-De la Cruz, D. B. Miles, B. Heulin, E. Bastiaans, M. Villagrán-Santa Cruz, R. LaraResendiz, N. Martínez-Méndez, M. L. CalderónEspinosa, R. N. Meza-Lázaro, H. Gadsden, L. J. Avila, M. Morando, I. J. De la Riva, P. Victoriano-Sepulveda, C. F. Duarte-Rocha, N. Ibargüengoytía, C. AguilarPuntriano, M. Massot, V. Lepetz, T. A. Oksanen, D. G. Chapple, A. M. Bauer, W. R. Branch, J. Clobert, J. W. Sites Jr. 2010. Erosion of lizard diversity by climate change and altered thermal niches. Science 328: 894 899.

Sinervo, B., D. B. Miles, N. Martínez-Méndez, R. LaraReséndiz, F. R. Méndez-delaCruz. 2011. Response to comment on "Erosion of lizard diversity by climate change and altered thermal niches". Science 332: 537.

Smith, G. R. 1998. Habitat-associated life history variation within a population of the Striped Plateau Lizard, Sceloporus virgatus. Acta Oecologica 19: 167-173.

Smith, G. R. and R. E. Ballinger. 1994a. Temporal and spatial variation in individual growth in the spiny lizard, Sceloporus jarrovi. Copeia 1994: 1007-1013.

Smith, G. R. and R. E. Ballinger. 1994b. Temperature relationships in the high-altitude viviparous lizard, Sceloporus jarrovi. American Midland Naturalist 131: $181-189$.

Smith, G. R., R. E. Ballinger, and J. W. Nietfeldt. 1994. Elevational variation of growth rates in neonate Sceloporus jarrovi: an experimental evaluation. Functional Ecology 8: 215-218.

Tingley, R., P. J. Mahoney, A. M. Durso, A. G. Tallian, A. Morán-Ordóñez, and K. H. Beard. 2016. Threatened and invasive reptiles are not two sides of the same coin. Global Ecology and Biogeography 25: 1050-1060.

Tinkle, D. W. 1967. The life and demography of the sideblotched lizard, Uta stansburiana. Miscellaneous Publications Museum of Zoology, University of Michigan 132: 1-182.
Tinkle, D. W. 1969. Evolutionary implications of comparative population studies in the lizard Uta stansburiana. Pp. 132-154 in Systematic Biology. Washington. National Academy of Sciences Publication no. 1692.

Tinkle, D. W., and N. F. Hadley. 1973. Reproductive effort and winter activity in the viviparous montane lizard Sceloporus jarrovi. Copeia 1973: 272-277.

Tomović, L., A. Urošević, T. Vukov, R. Ajtić, K. Ljubisavljenić, I. Krizmanić, D. Jović, N. Labus, S. Dordević, M.L. Kalezić, G. Džukić, and L. Luiselli. 2015. Threatening levels and extinction risks based on distributional, ecological and life-history data sets (DELH) versus IUCN criteria: example of Serbian reptiles. Biodiversity and Conservation 24: 2913-2934.

Van Devender, R. W. 1982. Comparative demography of the lizard Basiliscus basiliscus. Herpetologica 38: 189208.

Vazquez-Díaz, J., H. Gadsden, G. E. Quintero Díaz, P. Ponce-Campos, P. Lavin. 2007. Sceloporus cyanostictus. IUCN Red List of Threatened Species. Version 2012.2.

Villagran-Santa Cruz, M., O. Hernandez-Gallegos, and F.R. Méndez-de la Cruz. 2009. Reproductive cycle of the lizard Sceloporus mucronatus with comments on intraspecific geographic variation. Western North American Naturalist 69: 437-446.

von Bertalanffy, L. 1951. Metabolic types and growth types. American Naturalist 85: 111-117.

von Bertalanffy, L. 1957. Quantitative laws in metabolism and growth. Quarterly Review of Biology 32: 217-231.

Waldschmidt, S. 1980. Orientation to the sun by the iguanid lizards Uta stansburiana and Sceloporus undulatus: hourly and monthly variations. Copeia 1980: 458-462.

Whitford, W. G. and F. M. Creusere. 1977. Seasonal and yearly fluctuations in Chihuahuan Desert lizard communities. Herpetologica 33: 54-65.

Wiens, J. J., C. A. Kucziynski, S. Arif, and T. W. Reeder. 2010. Phylogenetic relationships of phrynosomatid lizards based on nucler and mitochondrial data, and a revised phylogeny for Sceloporus. Molecular Phylogenetics and Evolution 54: 150-161.

Editor: Steven Poe 